\title{
INTERNATIONAL ATOMIC ENERGY AGENCY
}

\begin{abstract}
HE first annual report of the Board of Governors of the International Atomic Energy Agency to the General Conference* covers the period October $23,1957-J u n e ~ 30,1958$, in which the membership of the Agency rose from twenty-six to sixty-six. Much of the work of creating the technical and administrative services needed both to implement the initial programme, which allots high priority to activities that will give the maximum benefit from the peaceful application of nuclear energy in improving the conditions and raising the standard of living of people in the under-developed areas, and to coordinate the Agency's activities with those of the United Nations and the Specialized Agencies, has been completed and operations commenced in some of the fields assigned by its statute. Excluding posts in the Division of Language Services, some two-thirds of the established posts in the Agency are in the scientific and technical divisions, and in the 111 professional staff appointed by June 30, 1958, twenty-eight nationalities were represented. Deputy directorsgeneral were appointed in December for each of the three technical departments : training and information; technical operations; and research and isotopes. Experience so far has confirmed the Preparatory Commission's expectations that initial activities in regard to the supply of materials, reactors and safeguards would consist largely of planning, collecting and exchanging information, surveys and technical advice.

The major technical assistance activity already operating is the Agency's international training programme, which embraces the training of specialists in all important peaceful applications of nuclear energy by the award of training fellowships and exchanges of scientists and experts. For these fellowships a fund of 250,000 dollars was established, and in addition 268 subsidized or fully paid fellowships for

* First Annual Report of the Board of Governors of the International Atomic Energy Agency to the General Conference covering the period from 23 October 1957 to 30 June 1958 . Pp. ii +53 . (Vienna International Atomic Energy Agency, 1958.)
\end{abstract}

training and research in institutions in their own countries were offered by member States. A field study is being made in Latin American countries to determine their requirements for training in the peaceful uses of nuclear energy and the availability of existing facilities. It is expected that the basic technical library will be functioning by the end of 1958, and the Agency's scientific and technical documentation service is already providing abstracts of scientific material and specialized bibliographies. It is also proposed to issue lists of all conferences in this field held throughout the world and to assist member States and scientific and technical organizations in planning and timing such meetings.

A provisional manual on radiation protection is planned, and an expert panel has been convened, while the collection and evaluation of data on the disposal of radioactive waste have commenced. The reactor programme will be divided into the physics and chemistry of reactors ; problems of engineering ; and production of nuclear energy. Data are being collected for an international reactor directory covering all types of power, research and training reactors. Under isotopes and research, plans are being made for forming composite isotope teams, including experts on applications of radioisotopes and radiation, to be sent on request to countries in the less-developed areas, and a survey is being made with a view of compiling an international catalogue of radioisotopes. The work of the Ageney is further displayed in its Programme and Budget for 1959*, in which an analysis of its proposed expenditure of $6 \cdot 725$ million dollars (including 550,000 dollars on scientific information and conferences, 2.575 million dollars on technical assistance and 1.050000 million dollars on regulatory activities) is accompanied by a description of the functions and programme of each of its departments.

* International Atomi. Fuergy Agener Pregramme and Budget * International Atomic Fnergy Ageney. Programme and Budget
for 1959. Pp. vii +94 . (Vienna: International Atomic Energy Agency, 1958.)

\section{NETHERLANDS-NORWEGIAN JOINT ESTABLISHMENT FOR NUCLEAR ENERGY RESEARCH}

\begin{abstract}
THE sixth annual report* of the NetherlandsNorwegian Joint Establishment for Nuclear Energy Research (J.E.N.E.R.), the joint research and training centre sponsored by the Dutch Reactor Centrum Nederland (R.C.N.) and the Norwegian Institut for Atomenergi (I.F.A.), which has now been published, describes the work of the Establishment during the period July 1, 1956--June 30, 1957. Tho governing board consists of a joint commission comprising three Dutch and three Norwegian members, and the work of the Establishment is directed by Mr. Gunnar Randars, who was appointed by the Institut for Atomenergi with the approval of the Reactor Centrum Nederland. The staff is grouped into six divisions--physies, engineering, civil engin-

* Sixth Annual Report, July 1956-June 1957, of the NetherlandsNorwegian Joint Fstablishment for Nuclear Energy Research. Pp. 31. (Kjeller, near Lillestrom: JEN ER, 1958.)
\end{abstract}

eering, chemistry, isotopes, and health physics-in addition to the administration, and during the period under review totalled 180 , of which fifty-four are classified as scientists and engineers and sixty-four as technicians and skilled workers.

The research reactor, JEEP, which is fuelled with natural uranium and moderated and cooled by heavy water and which is situated at Kjeller, was in almost continuous operation at $450 \mathrm{~kW}$. during the year, and approximately $92 \mathrm{MW}$. days of energy were released. Complete shut-downs occurred only for holidays and for the semi-annual inspection work. The Halden boiling-water reactor (HBWR) which uses heavy water, and which was designed by the Establishment, is being built by the Institut for Atomenergi and is now at an advanced stage of construction; it was expected to go critical some time during 1958. The civil engineering work has been completed; the 